\title{
Measurement of Effectiveness of Flexibility in Sustainable Supply Chain
}

\author{
Pawan Kumar ${ }^{1}$, Darshan $\mathrm{Kumar}^{2}$, Seema ${ }^{3}$ \\ ${ }^{I}$ Research scholar, I. K. Gujral Punjab Technical University, Jalandhar, India. \\ ${ }^{2}$ Director, Swami Sarvanand Institute Engineering \& Technology, Dinanagar, Punjab. \\ ${ }^{3}$ HOD, Department of Chemical Engineering, Beant college of engineering, Gurdspur
}

\begin{abstract}
In today industrial environment, flexibility is considered as an important differentiator for sustainable management in supply chain. Several researches already emphasized the need for flexibility although little attention has been paid on flexibility factors in sustainable supply chain. In this paper, different flexibility in sustainable supply chain has been identified and analyzed. Clear understanding of these flexibilities will help organizations to manage their resources in an efficient and effective way for sustainable management in supply chain. The proposed competitiveness index will help practicing managers to understand the weak areas. The present research work has immense theoretical importance and helpful for practitioners working on flexibility in sustainable supply chain management.
\end{abstract}

Keywords: Sustainable supply chain, Flexibility factors, ISM.

\section{Introduction}

Supply chain management (SCM) is an effective approach through which links between the factors is established and the production of the company increased with cost reduction. In present business scenario, there is need of optimization of business activities. This gave rise to the adoption of SCM principles in service sectors (Pramod and Banwet, 2010). Supply chain management has different issues which affect the supply chain, like risk management, operational management and sustainable supply chain management. Sustainability in supply chain includes social, economical and environmental aspects and encourage for better improvement in life cycle of products and services. Sustainable supply chain management can be regarded as the improved management of supply chains regarding social, economic and environmental issues. Through the integration of these issues, SCM plays an important role both in supply chain and environmental management (Correia et al., 2017). The main drivers for this transition have the rapid consumption and increasing pollution of natural resources due to massive economic development and uncontrolled urbanization (Salmona et.al 2010). The sustainable supply chain management reduces the cost of the product and increased the customer's satisfaction, sales of the product and the overall efficiency of the firm (Kananan et al., 2016). Flexible production is the key of sustainable supply chain. Flexibility plays an important role in the production system. Flexibility is essential for sustainable management in supply chain with competitiveness. Managers need to focus on total flexibility rather than individuals. Today FMSs are not restricted to the machining parts, but is used in every phase of a manufacturing process (Rao and parnichkun 2009; Dubey \& Ali, 2014). To produce products of global quality and according to the customer's need, Indian industries have to adapt flexibility in their manufacturing systems. Today there is emphasis on quality and variety than on quantity (Dubey \& Ali, 2014). To beat competition in the market industries have to be agile and adaptable. According to the market needs Indian industries realizes the need for flexible sustainable supply chain. For the analysis of flexibilities in sustainable supply chain management, a method of effectiveness index is used. The main objective of this paper is

- To identify and analyze the impact of different flexibility in sustainable supply chain. 


\section{Literature Review}

Sandeepa and Chand (2018) discussed the structural relationship among the flexibilities in supply chain. Dubey et al. (2017) suggested a SSCM framework contributing to knowledge-based view theory and systems theory (ST). Stephen and Brain (2003) present a framework for analyzing the benefits of flexibility in multistage supply chains, and develop a flexibility measure. Karen et al. (2012) developed a multifaceted scale for supply chain flexibility through an empirical investigation. They consider supply chain flexibility can be operationalized as a second-order factor model consisting of four dimensions, i.e. source, operations, distributions and information flexibility. Gong (2008) developed a model to measure supply chain flexibility with total system flexibility measured by an economic index. This flexibility model comprises labour flexibility, machine flexibility and routing flexibility. Kanchan Das (2011) firstly develops models for capacity, product mix, distribution and input supply flexibility and determines their optimal flexibility with mathematical programming model whose objective is profit maximization. Lee et al. (2010) present a method for measuring supply chain flexibility. Three unilateral flexibility measures (time, quantity and cash-flow flexibility) were put forward for each node enterprise. Then, the supply chain flexibility was integrated as a weighted sum of the three measures. Neural network method was used to determine the weights of the three unilateral measures. Before Lee et al. (2010) and Pujawan (2004) conducted a similar research in which presents a framework for assessing supply chain flexibility. Four dimensions of flexibility are identified including flexibility of product delivery system, production system, product development and supply system. Beamon (1999) measures supply chain performance using three indicators (resources, output and flexibility), and identifies four types of flexibility in a supply chain: volume flexibility, delivery flexibility, mix flexibility and new product flexibility. Sharma and Dagar (2015) identified the different type of flexibilities and analyzed them using W-ISM technique.

Table 1: Flexibility with their definitions

\begin{tabular}{|l|l|l|}
\hline S. No. & Flexibility & \multicolumn{1}{|c|}{ Definition } \\
\hline 1 & Environmental flexibility & $\begin{array}{l}\text { Firm ability to response to change in its environmental to rapidly and } \\
\text { slow cost. }\end{array}$ \\
\hline 2 & Technological Flexibility & $\begin{array}{l}\text { The dimension of process flexibility refers to the ability of } \\
\text { a technology's technical and management processes to accommodate } \\
\text { change. }\end{array}$ \\
\hline 3 & Manufacturing Flexibility & $\begin{array}{l}\text { A flexible manufacturing system (FMS) is a manufacturing system in } \\
\text { which there is some amount of flexibility that allows the system to } \\
\text { react in case of changes, whether predicted or unpredicted. }\end{array}$ \\
\hline 4 & Sourcing Flexibility & $\begin{array}{l}\text { Sourcing flexibility is an increasingly important building block of } \\
\text { supply chain flexibility }\end{array}$ \\
\hline 5 & Vendor flexibility & $\begin{array}{l}\text { Vendor flexibility. Vendor flexibility refers to the collective types of } \\
\text { flexibilities offered by different vendors in the supply chain. }\end{array}$ \\
\hline 6 & $\begin{array}{l}\text { Logistics flexibility } \\
\text { Supplier flexibility }\end{array}$ & $\begin{array}{l}\text { Flexibility in logistics management is one of the most important } \\
\text { challenges. It includes quickly response as per industry requirement. } \\
\text { environmental uncertainties. It includes providing the row material as }\end{array}$ \\
\hline
\end{tabular}




\begin{tabular}{|l|l|l|}
\hline 8 & Machine flexibility & $\begin{array}{l}\text { Machine flexibility is the ability to create different product types or } \\
\text { change the order in how processes are operated. }\end{array}$ \\
\hline 9 & Employee flexibility & $\begin{array}{l}\text { Flexibility in the workplace allows employers and employees to } \\
\text { make arrangements about working conditions that suit them. }\end{array}$ \\
\hline
\end{tabular}

\section{Evaluation of effectiveness index}

For the evaluation of effectiveness index, a questionnaire was designed on a five-point Likert scale. It consists of different flexibility of sustainable supply chain. Nine flexibilities are considered through literature and discussions with experts which are shown in Table 1. The respondents were asked to indicate the level of difficulty in managing these flexibility in sustainable supply chain, on the Likert scale, 1 for not at all and 5 for very important.

For computing the effectiveness index the mean score with their rank of flexibility factors has been calculated on the basis of Table 2. After this rank, inverse rank and weight for each factor is to be finding out. For assigning weight to different factors of effectiveness index, the highest and lowest values of five point Likert scale i.e. 5 and 1 are mapped $100 \%$ and $0 \%$ respectively. For each of the issues of effectiveness a weight is assigned. The criteria for weight (Wi) is as under:

$\mathrm{Wi}=+1$ (Strength), when percentage score $>60 \%$ (Mean value $>3$ ).

$=0$ (Neutral), when percentage score is between $40-60 \%$ Mean value between 2 and 3 ).

$=-1$ (Weakness), when percentage score $<40 \%$ (Mean value <2). This framework was given by Cleveland et al 1989 is $\mathrm{Cj}=$ Sum [Wi Log Ki]. Chand and Singh (2010) have also used this model for study the select issues of supply chain management.

Sum of entries of last column (Wi Log Ki), will give effectiveness index i.e. 5.257. Theoretically, effectiveness index value may range between -5.558 to +5.558 . Computation of effectiveness index for this study is illustrated with the help of a worksheet as shown in Table 2 .

Table-2: Rank Distribution

\begin{tabular}{|c|l|l|l|l|l|l|l|}
\hline S. No. & Flexibility & Mean & Rank & $\begin{array}{l}\text { Inverse } \\
\text { Rank(Ki) }\end{array}$ & Log Ki & $\begin{array}{l}\text { Weight } \\
(\mathrm{Wi})\end{array}$ & $\begin{array}{c}\text { Wi } \\
\text { Log Ki }\end{array}$ \\
\hline 1 & Environmental flexibility & 4.21 & 1 & 9 & .954 & +1 & .954 \\
\hline 2 & Technological Flexibility & 4.05 & 2 & 8 & .903 & +1 & .903 \\
\hline 3 & Manufacturing Flexibility & 3.89 & 3 & 7 & .845 & +1 & .845 \\
\hline 4 & Sourcing Flexibility & 3.61 & 4 & 6 & .778 & +1 & .778 \\
\hline 5 & Vendor flexibility & 3.49 & 5 & 5 & .698 & +1 & .698 \\
\hline 6 & Logistics flexibility & 3.26 & 6 & 4 & .602 & +1 & .602 \\
\hline 7 & Supplier flexibility & 3.16 & 7 & 3 & .477 & +1 & .477 \\
\hline 8 & Machine flexibility & 2.98 & 8 & 2 & .301 & 0 & .000 \\
\hline 9 & Employee flexibility & 2.83 & 9 & 1 & .000 & 0 & .000 \\
\hline
\end{tabular}

\section{Results and conclusion}

Based on response from questionnaire survey on various flexibility factors, effectiveness index for the flexibilities in sustainable supply chain has been evaluated (Table 2). Effectiveness index has been found to be 5.257. Maximum value can reach up to 5.558. Presently effectiveness index of this study among these factors is quite high. It has been observed that organizations are doing quite well in environmental flexibility, technological flexibility, manufacturing flexibility, sourcing flexibility, vendor flexibility, logistics flexibility 
and in supplier flexibility but still there is a need of improvement in machine flexibility and employee flexibility. This approach can be utilized by the organization to benchmark its performance with national and international standards. It can also help in strength and weakness analysis of the organizations. The identified factors need to be overcome by the management of the firms. This research indicates that different supply chains have different flexibility. We need to identify what is the most appropriate magnitude of flexibility to specific supply chains, and how to obtain the flexibility.

\section{References}

[1] Angel Martínez Sánchez, Manuela Pérez Pérez, Rhonda R. Lummus. (2003), Industrial Management \& Data Systems, Vol 103, No 6, pp.76-89.

[2] Biswas, S. and Narahari, Y. (2004) 'Object oriented modeling and decision support for supply chains', European Journal of Operational Research, Vol. 153, No. 3, pp.704-726.

[3] Chand, M. Raj, T. and Shankar R. (2014), Analysing The Operational Risks In Supply Chain By Using Weighted Interpretive Structural Modeling (W-ISM) Technique. International Journal of Services and Operations Management, Vol. 18, No. 4, pp. 378-403.

[4] Chand, M. Raj, T. and Shankar R. (2015), Weighted-ISM technique for analyzing the competitiveness of uncertainty and risk measures in supply chain. International Journal of Logistics Systems and Management, Vol. 21, No. 2, pp.181-198.

[5] Chand M. and Singh R.K. (2010), Study of Select Issues of Supply Chain Management: A Case Study, International Journal of Advanced Manufacturing Systems, Vol. 1, No. 2, pp.151-155.

[6] Chen, F., Drezner, Z., Ryan, J.K. and Simchi-Levi, D. (2000) 'Quantifying the bullwhip effect in a simple supply chain: the impact of forecasting, lead times, and information', Management Science, Vol. 46, No. 3, pp.436-443.

[7] Edmund, Prater, Biehl Markus, and Alan Smith Michael. 2001. "International Supply Chain Agility - Tradeoffs between Flexibility and Uncertainty.” International Journal of Operations and Production Management Vol.21, No. 5,pp 823-839.

[8] Griffiths, J. and Margetts, D. (2000) 'Variation in production schedules - implications for both the company and its suppliers', Journal of Materials Processing Technology, Vol. 103, No.1, pp.155-159.

[9] Khan, O., Christopher, M. and Burnes, B. (2008) 'The impact of product design on supply chain risk: a case study', International Journal of Physical Distribution and Logistics Management, Vol. 38, No. 5, pp.412-432.

[10] Malhotra, M. and Grover, V. (1998) 'An assessment of survey research in POM: from constructs to theory', Journal of Operation Management, Vol. 16, No. 4, pp.407-425.

[11] Martin, C., and M. Holweg. (2011). "'Supply Chain 2.0': Managing Supply Chains in the Era of Turbulence.” International Journal of Physical Distribution \& Logistics Management Vol. 41, No. 1, pp. 63-82.

[12] Mohanty, A. K., M. Misra, and L.T. Drzal. (2002) "Sustainable bio-composites from renewable resources: opportunities and challenges in the green materials world," Journal of Polymers and the Environment, Vol. 10, No. 1-2, pp. 19-26.

[13] Petersen, K. J., D. J. Prayer, and T. V. Scannell. (2000)“An empirical investigation of global sourcing strategy effectiveness,” Journal of Supply Chain Management, Vol. 36, No. 2, pp. 29-38.

[14] Raj, T., Shankar, R. and Suhaib, M. (2009) 'An ISM approach to analyze interaction between barriers of transition to flexible manufacturing system’, Int. J. Manufacturing Technology and Management, pp.417-438.

[15] Ravi, V. and Shankar, R. (2005) 'Analysis of interactions among the barriers of reverse logistics', Technological Forecasting and Social Changes, Vol. 72, No. 8, pp.1011-1029.

[16] Ravi, V., Shankar, R. and Tiwari, M.K. (2005) 'Productivity improvement of a computer hardware supply chain', International Journal of Productivity and Performance Management, Vol. 54, No. 4, pp.239-255.

[17] Sethi, A.K. and Sethi, S.P., (1990), "Flexibility in manufacturing: a survey." International Journal of Flexible Manufacturing Systems, Vol. 2, No.4, pp 289-328.

[18] Singhal, K. and J. Singhal. (2013) "Opportunities for developing the science of operations and supply-chain management," Journal of Operations Management, Vol. 30, No 3,pp. 245-252.

[19] Tachizawa, E.M. \& Thomsen, C.G., (2007). Drivers and sources of supply flexibility: an exploratory study. International Journal of Operations \& Production Management, Vol. 27, No10, pp.1115-36.

[20] Talluri, S. \& Narasimhan, R., (2004) A methodology for strategic sourcing. European Journal of Operational Research, Vol. 154, No.1, pp.236-250. 
[21] Vickery, S., Calantone, R. \& Dröge, C., 1999. Supply Chain Flexibility: An Empirical Study. The Journal of Supply Chain Management, Vol.35, No.3, pp.16-24.

[22] Vokurka, R.J., O’Leary-Kelly, S. (2000), "A conceptual model of supply chain flexibility", Journal of Operations Management, Vol. 1103 No. 6.

[23] Wadhwa, S., and K. S. Rao. (2004). "A Unified Framework for Manufacturing and Supply Chain Flexibility." Global Journal of Flexible Systems Management Vol. 5, No.1, pp. 29-36.

[24] Warfield, J. (1974.) 'Developing interconnected matrices in structural modeling', IEEE Transactions on Systems Men and Cybernetics, Vol. 4, No. 1, pp.51-81.

[25] Warfield, J. (1987) 'Interpretive structural modeling', in Singh, M.G. (Ed.): Systems \& Control Encyclopedia Theory, Technology, Applications, pp.2575-2580, Pergamon.

[26] Yang, A-Ting, and Lin-Du Zhao. (2011) "Supply Chain Network Equilibrium with Revenue Sharing Contract under Demand Disruptions." International Journal of Automation and Computing Vol. 8, No.2, pp. 177-184 